Article

\title{
International Students' Experiences at a Saudi University and Academic Leaders' Perceptions Regarding Them
}

\author{
Yousef Mubrik N. Almutairi
}

College of Education, University of Ha'il, P.O. Box 2240 Ha'il, Saudi Arabia; yo.almutairi@uoh.edu.sa

Received: 20 July 2020; Accepted: 17 September 2020; Published: 20 September 2020

\begin{abstract}
This qualitative study addresses international students' experiences at a Saudi university to gain insight into the challenges these students encounter during their studies. The study also explores academic leaders' perceptions in supporting international students. The guiding theories behind this study include culture shock and socialization. I conducted interviews with 16 international students and 10 academic leaders at a university in the Kingdom of Saudi Arabia to gain an understanding of their perspectives. The findings were then analyzed for common trends. The interviews showed that some students experienced greater culture shock than others, including language barriers, when coming from non-Arab countries, and women faced more challenges than men. Meanwhile, the academic leaders and faculty in this study appeared to understand international students' experiences. Despite the rise in international students attending Saudi universities on full scholarships, limited research has considered this unique student population. This study addresses this gap and discusses future directions. This paper discusses implications for higher-education personnel and international students. The paper recommends providing sufficient material to allow students to prepare for culture shock before coming to Saudi Arabia and making professors and personnel more available to students for support.
\end{abstract}

Keywords: international student experience; language barrier; culture shock; Saudi higher education; academic leaders

\section{Introduction}

International students are an important part of the Kingdom of Saudi Arabia's educational landscape, but little is known about their experiences upon entering the country's universities. The Kingdom of Saudi Arabia (KSA) is keen to attract diverse students to their higher education institutions. The number of international students earning full-grant scholarships in Saudi universities has continued to increase throughout the past four decades, with more than 42,000 international students receiving such scholarships as of 2014 [1]. These students hail from more than 155 Arab, African, Asian, European, and American countries. Full-grant scholarships afford international students many privileges at Saudi universities: free tuition; free lodging; and a monthly allowance for books, transportation, and other needs [2]. They also receive free air travel to the KSA and a free round-trip ticket to visit home once per year. Full-grant scholarships have been offered for more than half a century to international students seeking to study in the KSA, with the international student and research exchange programs run by the Custodian of the Two Holy Mosques (for external scholarships and traditional scholarships) as the most prominent forms. Traditional scholarships are provided to support Saudi university students studying outside the KSA, while external scholarships are for non-Saudi students, intended to help them to share the message of Islam with the world, learn Arabic, and spread a culture of moderation [2]. External scholarships also enable students to cultivate scientific and cultural ties with Islamic and 
scientific educational institutions, promote diversity, and enhance solidarity between the KSA and the world [3]. In this study, "international students" refers to non-Saudi students pursuing a bachelor's degree at Saudi universities [3]. Essentially, international student enrollment represents a form of cultural and social exchange for domestic Saudi students and their international counterparts [2].

Despite the number of international students attending Saudi universities, there is scant English-language research considering their needs relative to academic and social success while studying in the country. Research in Arabic has explored various obstacles facing international students in the KSA, considering topics such as students' Arabic language proficiency, negotiating the higher education system (e.g., class performance), advisors' academic expectations, and a lack of access to support services (e.g., mental health and academic support) [2,4-6]. Some major challenges that international students encounter in Saudi Arabia are the language and culture barriers, which can lead to culture shock [7]. However, no English-language research appears to have focused on international students' experiences in Saudi universities. Scholars have also not considered how Saudi academic leaders perceive international students at Saudi universities. Accordingly, this study aims to address this gap and poses the following research questions:

(1) What are international students' experiences with culture shock at Saudi universities?

(2) What challenges do international students face when studying at Saudi universities?

(3) How do academic leaders perceive international students at Saudi universities?

\subsection{International Education}

Different histories, cultural influences, economic strengths, and locations lead different countries to have markedly unique approaches to virtually everything, including education. While the international perception over the last century has been that the United States' culture of innovation and its university system's emphasis on private-public partnership has created the best higher education system in the world, this perception is changing [8]. Perceptions of quality and value are not static and are highly influenced by changes in stakeholder perceptions of success, shifts regarding competitive forces within markets, and new social attitudes [3,9-22]. For example, while conceptions of "quality" and "value" in the service industry are based upon previous experience, personal expectations, and institutional image, in higher education, they may derive from institutional reputation, esteem of research, the volume of work published, and postgraduate employability rates [23].

While the United States' higher education system has been historically held in the highest esteem, the UK, Germany, France, Canada, and other developed nations all have higher education institutions of international prominence. While their particular organization styles and pedagogical methodologies vary, their standards of excellence and scopes of contribution to global scholarship are similarly high [24]. As Asia's international economic influence continues to expand, Asian universities are becoming increasingly prominent on the global stage. Singapore and Hong Kong's universities, in particular, are gaining high esteem, encouraging some wealthier students who may otherwise go abroad for university to continue their education at home [24].

In the interest of continuing to expand and strengthen their university systems in an increasingly globalized market, established universities have begun to create international satellite campuses to attract students in regions with high economic growth [8,25-27]. These satellite campuses provide students who are unable to afford international tuition and travel with a means of obtaining a world-class education and access to the resources that a top university can grant. Countries with a wealth of resources, growing manufacturing infrastructures, and rapidly developing economies-particularly, India, China, and the KSA-recognize that granting strong local students access to exceptional universities is a promising investment in national economic growth [28]. These elite institutions allow students to gain new frameworks for understanding the economic possibilities of their country, challenge themselves to succeed in new ways, and make connections within an elite international alumni network [29]. This interconnected, international model for elite universities suggests promise 
for their continuing esteem, prestige, and existence. Certain countries within the developing world are also attracting international students, such as South Africa, Malaysia, and the United Arab Emirates. By 2020, it is expected that nearly 7 million international students will be attending school in one of these three nations, tripling international enrollment from 2010 [12].

International students often find that adjusting to Western university life is challenging. When entering a new university, international students expect to forge meaningful relationships with locals, to receive academic support from the institution, to receive social support from their peers, to be in a safe environment that ensures their wellbeing, to feel welcome, and to enjoy their time in their new country [29]. Despite their best efforts, a multitude of challenges often come up. Cultural gaps; language barriers; and differences in religious practice, weather conditions, and approaches to studying and school in general act as clear obstacles to assimilation [1,3,8-23,25-27,29-34]. International students from non-Western countries expect courses to be much tougher in the West compared to in their home country [35]. However, international students do not anticipate facing culture shock and encountering psychological differences [29]. The immense lifestyle shift of attending school in a new country can take its toll, and loneliness can have a profound effect on international students, who end up in a new country without the community and support systems they have become accustomed to [9-13,23,28,30,35-42]. While many international students end up forging meaningful relationships with their fellow classmates, regardless of whether they have a shared nationality, the cumulative effect of these alienating experiences can make for a stressful transition [14]. Despite these risks and potential setbacks, many international students push forward in their studies, driven to make a better life for themselves and capitalize on economic growth in their countries. International students in Saudi Arabia go through the same experiences as those in Western countries in terms of culture shocks and university-life challenges.

\subsection{Education in the Kingdom of Saudi Arabia}

The KSA holds a deep-seated commitment to and appreciation for education and is committed to cultivating international links. Indeed, the country's Ministry of Education [31] has named the internationalization of higher education one of the most important criteria contributing to educational quality and fostering a competitive environment among students. Aba Al-Khail [43] explained that the full-grant scholarship program for international students studying in the KSA is rooted in an interest in a calling from God to educate Muslim students. This program thus represents a service to Islam and to educating the children of Muslims. Grant scholarships are also intended to meet the needs of Islamic individuals specializing in Islamic sciences and the Arabic language. Since ancient times, students have come to the KSA from all over the world to study and learn from Islamic scholars $[2,5]$. However, international students in Saudi universities may experience psychological fatigue and discomfort due to stark differences in Saudi culture, customs, and traditions compared to their own. Research has shown that these students also struggle with homesickness, being away from both their families and their home culture [2]. In addition to social stresses, international students in the KSA may encounter educational issues (e.g., instructors' use of colloquial Arabic when teaching), economic problems such as insufficient funds to buy textbooks (based on the monthly allowance provided by the scholarship), and limited transportation (e.g., bus routes only running twice daily) [2,6]

International students' struggles in adjusting to life in Saudi Arabia may be compounded by a lack of support in problem solving. Al-Mohsen and Al-Sa'wi [2] noted that international students generally do not attend routine meetings with faculty or student affairs staff to discuss educational and administrative issues. Services related to housing and transportation were also reportedly insufficient. The author also found that domestic students may treat their international peers unfairly, making it difficult for these groups to develop friendships. Additionally, international students may possess limited knowledge of the system and nature of study at their university. Classroom barriers, such as difficulty posing questions and understanding unfamiliar Arabic words, can further complicate international students' adjustment [2]. 
The language barrier is one of the most critical obstacles for international students at Saudi universities. Mori [18] noted that a "lack of English language skills is likely to affect international students' academic and social performance, which, in turn may affect their psychological adjustment to the new culture" (p. 138). Although this refers to education in the English language, international students in the KSA are sure to experience the same problem. International students may find it especially difficult to communicate in Arabic because its alphabet is drastically different from that of languages using the Roman alphabet [2].

Just as students from Arabic countries studying in English-speaking countries must learn to read, write, and think in academic English, as well as understand English humor, slang, and colloquialisms [7], international students in Saudi universities face similar struggles. The classroom environment is very different from that of, for example, American universities. For instance, there is little student-instructor interaction in Saudi classrooms [32].

\subsection{Gaps in the Literature}

As noted earlier, the KSA's grant scholarship program has drawn international students to Saudi campuses for nearly 40 years [1]. Most Arabic-language studies on this population have involved case studies of international students and their perceptions of the Saudi learning environment in contrast to that in their home country [2]. However, such studies have tended to focus on international students in general rather than their specific experiences and challenges. Additionally, scholars have not explored academic leaders' roles in supporting international students or how students perceive the aid of these leaders.

\subsection{Purpose of the Study}

Given the number of international students coming to the KSA, it is important to examine (a) their academic experiences and (b) how academic leaders perceive these international students. The academic and cultural differences between the KSA and students' home cultures also warrant investigation. This study seeks to bridge the gaps in the literature discussed above by exploring international students' experiences at a Saudi university to gain insight into the advantages and challenges these students encounter when studying abroad. A clearer understanding of international students' experiences should offer meaningful implications for academic advisors, institutional leaders, and international students preparing to travel and study in the KSA.

\subsection{Theoretical Framework}

This study takes the theoretical construct conceptualization on culture shock as a guiding framework, referring to the bewilderment evoked when an individual encounters another culture through relocation, study abroad, or an extended visit [20]. Oberg [19] was one of the first scholars to operationalize culture shock and delineated five phases. In the honeymoon stage, an individual envisions what life may be like in the new culture, which is followed by dismissal as the individual acknowledges immense social contrasts. In the second stage, the individual becomes hostile to and irritated by these contrasts and endeavors not to make necessary changes. In the third stage, the individual recuperates and begins to gradually adjust to the culture, finally adapting to the new culture in the fourth stage. Finally, in the last stage, the individual may experience reverse culture shock upon returning home and reacclimating to their home country.

Sam and Berry [21] extended Oberg's [19] and Pederson's [20] work via the acculturation theory. Specifically, Sam and Berry [21] defined how groups of people and their individual members navigate intercultural contact and identified outcomes that could benefit all groups. The author suggested that all social groups are influenced by interaction; it is necessary to understand the social changes derived from people's efforts to adjust to a new culture mentally and socially. Such efforts could involve behavioral modification, such as in one's way of speaking, dressing, and eating. Individuals may also experience "acculturative pressure" [21], characterized by uneasiness, vulnerability, or despondency. 
The notion of culture shock is, in some ways, analogous to the acculturation process [44]. Researchers have developed various models of acculturation, such as Zhou et al.'s [44] ABC model, with " $\mathrm{A}$ " encompassing affective features (e.g., stress and coping), "B" signifying behavioral characteristics (e.g., social skills), and " $\mathrm{C}$ " indicating cognition (e.g., attitude, self-esteem, and the ability to put oneself in another's shoes). The ABC model is more comprehensive than other culture shock models. Under this framework, cultural assimilation is conceptualized as a process rather than a one-time shock, is dynamic rather than static, and considers one's overall circumstances rather than individual traits. Essentially, the ABC model frames cross-cultural transition as a major life event requiring intensive adaptation [44]. These theories and models of culture shock/acculturation may help to explain international students' experiences while studying in Saudi universities.

\section{Materials and Methods}

Given the investigatory nature of this study, I adopted an interpretivist exploratory qualitative design [3,9-15,23,30,39-42]. Interpretivism looks to understand and interpret individuals' lived encounters and uses these encounters to illuminate praxis [15]. Interpretivism, likewise, distinguishes importance as socially constructed and determined by members through interactions with their reality $[3,9-17,23,28,30,35,37-42]$. In light of the paucity of literature on international students' experiences at Saudi universities and academic leaders' perceptions of these students, interpretivism appeared to be a feasible paradigm for investigating students' experiences and generating some practical insight [15]. I chose a case-study design for this investigation, given my focus on a specific phenomenon, namely, international students' adjustment to a Saudi educational setting [26,27,29,33]. The goal of this investigation was to decipher and examine international students' adjustment to Saudi university life. Together, the participants and I determined the importance of relevant factors through our interpretations. I also referred to the voices of numerous community members to uncover more information about international students' experiences.

\subsection{Participants}

Data were collected at a university, anonymized as Northern Kingdom University (NKU), in the northern part of the KSA with approval from the university's ethics board. The chosen institution is a relatively young, teaching-focused university. Of the student body, international students (602 undergraduates) make up only $4 \%$ of the population and represent 35 countries. Fifty undergraduate international students and 25 academic leaders at the university were invited to participate in this study; the researcher randomly sent emails asking if they could voluntarily participate in the study. Sixteen international students and ten academic leaders expressed interest, and they emailed the researcher back. I interviewed the men face to face and the women over the phone. All participants were assigned pseudonyms to protect their confidentiality. See Table 1 for students' pseudonyms and demographics and Table 2 for leaders' pseudonyms and university positions. All interviewed students were on full university scholarships. 
Table 1. Respondent profile (students).

\begin{tabular}{|c|c|c|c|c|c|c|}
\hline * Name & Major & Age & Nationality & $\begin{array}{c}\text { Length of Residence in } \\
\text { Saudi Arabia }\end{array}$ & Gender & $\begin{array}{c}\text { First } \\
\text { Language }\end{array}$ \\
\hline Marco & Arabic Language & 23 & Italy & 6 months & Male & Italian \\
\hline Budi & Arabic Language & 24 & Indonesia & 1 year & Male & Indonesian \\
\hline Maha & Art & 23 & Jordan & 3 years & Female & Arabic \\
\hline Hend & Education & 24 & Egypt & 8 years & Female & Arabic \\
\hline John & Islamic Studies & 23 & United States & 2 years & Male & English \\
\hline Omar & Computer Engineering & 25 & Morocco & 6 months & Male & Arabic \\
\hline Rada & Computer Engineering & 22 & Egypt & 2 years & Male & Arabic \\
\hline Alexi & Engineering & 24 & Russia & 3 years & Male & Russian \\
\hline James & Engineering & 23 & Philippines & 6 months & Male & Pilipino \\
\hline
\end{tabular}

Table 2. Respondent profile (academic leaders).

\begin{tabular}{cc}
\hline$*$ Name & Position at University \\
\hline Khaled & Dean \\
Mohanad & Dean \\
Salah & Department head \\
Ahmed & Department head \\
Yousef & Department head \\
Essa & Department head \\
Muqrin & Department head \\
Saad & Department head \\
Neyaif & Vice dean \\
Waleed & Vice dean \\
\hline
\end{tabular}

Note: * All names are pseudonyms.

\subsection{Data Collection and Analysis}

I obtained informed consent from all participants prior to conducting interviews, explaining that their participation was fully voluntary and informing them of the risks and benefits of the project [41]. I followed the standards for qualitative research and case-study techniques when conducting semi-structured interviews, which permitted the participants and myself to shift from initial questions to new themes. This approach also enabled me to probe respondents' reactions and pose clarifying questions [17]. Most interviews for this study were conducted one on one in Arabic, because the university's spoken language is Arabic, and lasted roughly $1 \mathrm{~h}$, while a few were conducted in English. Prompts included questions such as "Tell me about your experiences with culture shock at the university and the challenges you have faced". The interviews were digitally recorded and held in a mutually agreed-upon location. I also took notes on the time, place, and date of interviews along with a description of each interview from my perspective [10]. After each interview, I translated the information into English and recorded field notes, including my impressions, reactions, and affective and behavioral observations as outlined by Creswell [39]. After transcribing the interviews, I reviewed all the transcripts to ensure my comprehension of the text [38]. Creswell [39] suggested using pseudonyms and code words to protect participants, and I followed this recommendation. Lastly, I developed codes and themes, and then shared the responses with participants to ensure coding quality [16]. The data revealed themes about (a) international students' experiences at NKU, (b) how NKU's academic leaders perceived international students, and (c) students' experiences from a servant-leadership standpoint. 


\subsection{Study Rigor and Trustworthiness}

Jones et al. [10] emphasized the importance of researcher reflexivity in enhancing the rigor and trustworthiness of a study. I assessed the integrity of my research by being explicit in my research design and leaving an audit trail [42]. By sharing students' commentary, I hope that academic leaders will develop a greater awareness and understanding of international students at their university. Participants' personal data were protected by using pseudonyms in field notes to ensure "no one [experienced] harm or embarrassment as a result of insensitive research practices" [40]. This qualitative study can therefore be considered trustworthy. The participants were provided full information about what the study entailed, willingly gave consent to participate, and were not deceived about any aspect of the study.

\section{Results}

This study aimed to identify and document international students' experiences at NKU and how the university's academic leaders perceived these students. I carefully examined themes that emerged from the data and extracted quotations and examples from interviews to clarify and depict these themes. The overarching student themes, and the research questions addressed by each, are as follows: (a) culture shock (Research Question \#1), (b) language barrier and feeling discouraged (Research Question \#2), (c) cultural barriers and homesickness (Research Question \#2), (d) educational challenges (Research Question \#2), and (e) international students' need for support (Research Question \#2).

\subsection{International Student Themes}

\subsubsection{Culture Shock}

As I studied the interview transcripts, it became evident that 11 participants had experienced culture shock. Several related themes emerged from the interviews, including students' belief that they had received insufficient university support to help them adjust. Eleven students with no background in Arabic noted that the culture shock had been difficult, while students from an Arabic background did not report culture shock and generally described common experiences. Marco, a young man from Italy, had only been at NKU for a short period at the time of his interview, and he recounted his experience as follows:

I have only been here for one semester. I am very tired from all the studying and the process here, and honestly, I feel I am still shocked by everything. I am shocked at the food-people always eat rice. And the lifestyle is different for me, but I do not reject it and I have not isolated myself. I would love to know more and more about real Islamic culture. ... When I arrived in Saudi Arabia for the first time, I experienced culture shock. I think I'm still shocked. I've been here for almost six months, and I've tried to adjust to Saudi culture. But honestly, for the first month after I arrived here, I felt strange. I did not expect the culture shock to be [so] hard.

Culture shock resulted in Marco's disappointment with his study-abroad experience upon arrival, as he had difficulty assimilating; he discussed the cultural differences he experienced, especially in terms of meal times and how much rice Saudi citizens eat. A student from the UK, Jack, noted that he initially regretted his decision to attend NKU. After two weeks at the university, he wished he had not come to Saudi Arabia to study because student life in the UK "was great". He was "not prepared to come to study at a Saudi Arabian university and the hot weather is difficult". He had not expected to experience culture shock and faced difficulty adjusting to the weather in Saudi Arabia.

Nonetheless, the degree of culture shock faced by a student seems to depend on their background. A young Indonesian man, Budi, stated: 
There was a lot of stress [from the university, course, and life]. It's been difficult, and sometimes I worry about how to prepare for Arabic classes and adapt. But I did not really face culture shock because I am Muslim, and I like the culture here. Most Muslim students want to come and study here in Saudi Arabia, where Mecca and Medina are. My family also wants to come here, and I miss them.

Similarly, Maha said, "I'm an Arab from Jordan, and I love Saudi culture and did not experience culture shock". Hend, from Egypt, was also comfortable on campus: "I have all my family here in Saudi Arabia. My mom is a teacher here, and I did not get culture shock". A Syrian student, Saba, reported that she did not even perceive herself as an international student: "I actually don't think that anyone sees me as international because I don't see myself as different. Saudi culture is close to Syrian culture, except that universities in Syria are not segregated for men and women, so I did not get culture shock. However, it is difficult for me to communicate with men." This makes it clear that women face more challenges related to the custom of segregation between male and female students in Saudi Arabia, and face challenges communicating with men. Generally, participants from Arab countries did not face as much culture shock as other international students. For example, Marco and Jack seemed to have had much more trouble assimilating to their new environment, lifestyle, and weather.

\subsubsection{Language Barrier and Feeling Discouraged}

In addition to culture shock, most participants from non-Arabic countries were discouraged by the language barrier. Noah, from Canada, explained,

I'm having a hard time writing and talking in Arabic. One time, I went to go buy something from a store at the university, and [the employees] could not understand me. I left disappointed. Sometimes I have a hard time translating in my classes. In the first month, I felt like I was stupid, and I was thinking about going back home because I couldn't speak Arabic.

In a similar vein, American student John said,

The language, like how in Arabic we write from right to left and English is written from left to right, is difficult. It's hard to speak and write well in Arabic, and I always ask my friends to help me. I don't like if I talk and my teacher and Arab friends can't understand me.

Both these young men from the West faced challenges with the language in Saudi Arabia and became frustrated. Conversely, as with culture shock, students from Arabic cultures did not encounter the same obstacles. Rada, a young man from Egypt, admitted, "I do not have any challenges with the language. Arabic is my first language, so I'm really good at speaking and writing it." Students from Arabic countries were naturally able to smoothly navigate the language in Saudi Arabia.

\subsubsection{Cultural Barriers and Homesickness}

In addition to the language barrier, cultural barriers and missing one's family were other common "barrier" themes. As noted, international students at NKU generally faced unique challenges depending on their country of origin. A young Russian man, Alexi, indicated:

At first, I was uncomfortable due to the differences in Saudi culture, customs, traditions, social life, and the food. But after I got used to it, I started to love the culture, life, and the food. I like the way people dress here, and the people are generous, welcoming, and like to be helpful. I also got used to eating the food here-I like it.

James was also interested to discover Saudi culture: 
I am not knowledgeable about or aware of Saudi culture. It can be hard to socialize and make friends because I don't know about cultural and religious customs and social life. I'm still learning about Islamic culture because it interests me to know more, and I am Muslim so I'm reading more about it.

In addition to cultural barriers, participants also discussed missing their loved ones back home. Omar remarked, "I miss my family and their food. It's really hard to live away from them". James was similarly homesick, saying he spoke with his family nearly every day via Skype. In total, 12 participants experienced challenges related to the different customs, social life, food, and language, and felt homesick.

\subsubsection{Educational Challenges}

All participants experienced educational challenges at NKU. For instance, Ali from Somalia noted that Saudi Arabia offers good university education about Islam, but he had difficulty reaching the administrators: "It is hard to meet the faculty and make an appointment with them. There are no regular meetings with them to discuss my educational issues." He also lamented the cost of textbooks and the slow internet speed in his dormitory. Abdul, from Pakistan, echoed Ali's assessment of faculty members' accessibility: "There are few advisors to meet with if I need advice, and they're always busy." Rada shared similar sentiments, explaining, "It's hard to make an appointment with a professor because he says anyone can talk to him after class. So it's hard to see him".

A student from the Ivory Coast, Brahima, found the faculty's use of unfamiliar Arabic words to be an obstacle, saying, "It's hard to understand [them]". Abdul had difficulty with instructors' teaching approaches in general, mentioning that there was little variety in their methods. Although all the students interviewed claimed that their instructors were pleasant and helpful, students still struggled to meet with them, given how busy the instructors were. The students also experienced different social rules and customs in terms of dealing with professors.

\subsubsection{Need for Support}

Fourteen of the student interviewees wished for greater administrative support to manage culture shock and access university services. Noah explained, "When I arrived, there were many unfamiliar things I needed to look for and ask for, but my friends helped me". Mahesh, a young man from India, also shared his experience:

They didn't tell us about resources available at the university. There's a long process to get a room at the university, and there is no support. The supermarket is far away to buy water-there is no water available in the dorms.

Rada noted that he had needed to "figure out the university by [him]self" upon arriving on campus. He also mentioned how difficult it was to reach support services, saying, "If I send an email to get support from university offices, they don't reply. I have to go to the office and talk with them face to face".

Clearly, many of the international students interviewed felt they had been left to their own devices with minimal university support. All participants felt they needed more support, emphasizing the importance for international students of receiving sufficient guidance to adapt to their new circumstances and to be able to study in a positive, safe, and supportive environment.

\subsection{Academic Leader Themes}

In addition to gathering insight into students' experiences at NKU, academic leaders' perceptions of these students are also worthy of consideration. Therefore, I explored leaders' perceptions of international students, and the major themes to emerge from interviews with academic leaders were as follows: (a) academic leaders generally understand international students' experiences (Research Question \#3) and (b) academic leaders' expectations of international students (Research Question \#3). 


\subsubsection{Academic Leaders' General Understanding of International Students' Experiences}

All the academic leaders in this study indicated that they understood international students' experiences at the university and the issues these students may face. Waleed, a vice dean, and Yousef, a department head, agreed that members of NKU sought to support international students and help them overcome any problems. Waleed explained:

I understand how the environment has changed for international students, and I feel that here is different than where they came from. So I try as best I can to help them adapt and adjust to the university.

All the academic leaders also mentioned the cultural challenges some international students may confront. A dean, Mohanad, particularly empathized with students' struggles in relation to their religious background:

I understand [students'] experiences and culture shock. I work with [them] to try to help them adjust, especially if they are not Muslim. Most international students here that I know are Muslim, and they understand the culture and know it before they come here. Most Muslim students want to come to study in Saudi Arabia because it's the birthplace of Islam. Muslim students might miss their family, but non-Muslim students miss their family and experience bad culture shock.

Saad, a department head, mentioned the language barrier as another pertinent obstacle:

I understand that Arabic language is difficult for some international students, [as are] the teaching methods. However, faculty try their best to ease the course for international students and not make it hard for them. We support them in their needs.

Essa, a department head, mentioned the challenges international students may face in terms of coursework: "I know [there can be problems with] Blackboard and doing research because some students told me the Internet is slow in the dorms. So I try to give them extra time to do homework.". Another department head, Muqrin, claimed that the university strives to fully support international students by offering them free lodging, books, transportation and annual flights, and an allowance. Overall, academic leaders unanimously acknowledged the challenges facing international students and identified several ways in which the university and academic leaders strive to help.

\subsubsection{Academic Leaders' Expectations from International Students}

Of all the academic leaders who were interviewed, nine expected international students to contribute to the culture and university life. Khaled, a university dean, expects international students to assimilate to the culture and adjust to life in Saudi Arabia:

I understand the challenges faced by international students; we try our best to [hire] employees who enjoy teaching and are interested in helping international students, and expect the international students to participate in campus life with new perspectives. We also expect them to adjust to life here as well as to communicate their challenges with us so that we can help create a better environment for them.

Similarly, Nayeif-a vice dean-shared the following:

We expect administrators to understand advising and to make sure that the needs of international students are met because the university is hosting them. We, as university leaders, try our best to hire the best workers who know how to treat international students. Moreover, we expect international students to utilize the services provided by the university, as well as to immerse themselves in the culture and student life. We want these students to return to their countries with rich and varied experiences in Saudi Arabian higher education. 
Salah, a department head, conceded, "I expect international students to seek help more than other students, and expect them to visit my office for assistance". Another department head, Ahmed, also believes that international students face more challenges related to the Arabic language. He stated, "We as academics expect international students to work hard with the language; we are available for help".

\section{Discussion}

The study findings reveal several challenges international students face upon arrival and during their studies at NKU. Students cited an array of cultural challenges, including language barriers. This trend echoes prior research identifying the differences between Arabic and languages such as English, including the direction in which text is written [7]. The language barrier can also influence students' socialization and course completion.

Several international students in this study mentioned homesickness. The theoretical construct conceptualization on culture shock of Oberg [19] elucidates the stages through which individuals progress when immersed in a new culture, including during study abroad. In the context of this study, international students proceeded through the various stages of culture shock and tended to adapt if they had been in Saudi Arabia for two years or more. Students in the early stages of culture shock (those living in Saudi Arabia for less than one year) tended to express resistance to the culture and were homesick, embodying the dismissal stage. They, therefore, needed time to adjust. International students in Saudi Arabia undergo the same experiences as those in Western countries in terms of culture shock and university-life challenges. However, international students face particularly difficult challenges because of the cultural differences, such as food, social life, the climate, and clothes. Women faced more challenges than men because of the culture differences and the gender-based segregation of students. Under Zhou et al.'s [44] ABC model, the affective (i.e., stress and coping) dimension seemed more pertinent for students who had been at the university for a short time. Those who had attended the university longer expressed stronger indicators of cognition (e.g., self-esteem). Furthermore, echoing Al-Mohsen and Al-Sa'wi [2], the international students in this study did not feel they received sufficient support from faculty and staff in terms of their schooling and general needs.

While academic leaders at Saudi universities seem to be aware of the experiences of international students, the perspectives gleaned in this study may aid international students in adapting to Saudi life. Academic leaders should ensure that students are well-supported, empathically understood, and appreciated by educational authority figures. The academic leaders in this study generally understood the experiences of international students well; however, additional training in this regard may help these leaders to support international students more effectively.

\section{Conclusions}

Based on the findings of this study, NKU and similar institutions may benefit from implementing measures to facilitate international students' assimilation. First, students should be made aware of the potential challenges they may encounter even before they arrive on campus. University officials could prepare informational materials to be disseminated to students prior to their trip, highlighting common obstacles along with contact details for relevant support services. Additionally, universities' student-affairs offices, professors, and other personnel who work with international students should aim to address potential gaps in language, learning styles, and cultural understanding to better engage these students and help them to be successful. For example, universities in the KSA and other Arabic-speaking countries could offer an Arabic-language program specifically for international students. Students' ability to understand and speak Arabic would likely influence their success in classes and broader social settings. Implementing a language curriculum for non-native Arabic speakers could mitigate potential language barriers. Tutoring and other academic support services should also be provided to aid international students in their coursework as they adapt to Saudi culture. 
Additionally, university offices for international students should inform them about culture shock and assure them that challenges are to be expected, before they begin their study abroad. Academic leaders and other university officials should also continue to acknowledge the value of international students on campus, as doing so would underscore the importance of diversity for domestic and international students alike. Furthermore, as noted earlier, academic leaders, faculty, and staff should be trained in service to international students to ensure that students feel as though they are heard, supported, understood, and valuable members of the community. Academic leaders must be trained to fully address students' needs.

\section{Limitations and Future Research Directions}

This study had certain limitations that point to avenues for future research. The sample was limited to a small group of students and academic leaders from a specific university in Saudi Arabia. Thus, the findings may not be generalizable to students or academic leaders in other settings. Future research in different cultural or linguistic contexts and with larger samples is recommended to validate and expand these findings. Furthermore, the data were subjected to qualitative analysis. Studies using mixed-method approaches or quantitative methods may reveal distinct trends regarding international students' adjustment to living and studying in Saudi Arabia (or other Middle Eastern countries).

Funding: This research received no external funding.

Conflicts of Interest: The authors declare no conflict of interest.

\section{References}

1. Saudi Arabia Ministry of Education. Higher Education in the Kingdom of Saudi Arabia: Indicators and International Comparisons. 2019. Available online: https://www.moe.gov.sa/ar/ministry/deputy-ministryfor-planning-and-information-affairs/docs/dmpi_04.pdf (accessed on 4 December 2019).

2. Al-Mohsen, M.; Al-Sawi, M. Alienation among expatriate scholarship students at Qassim University: A demonstration and ways to confront it. J. Arab. Hum. Sci. 2015, 8, 2071-2115.

3. King Faisal University. International Students Scholarship. 2020. Available online: https://www.kfu.edu.sa/ ar/Deans/AdmissionRecordsDeanship/Pages/Scholarship.aspx (accessed on 26 December 2019).

4. Al-Harbi, M.I.J. Academic problems among scholarship students at the Islamic University from their perspective. Educ. J. 2015, 13, 265-316.

5. Al Maghamsi, S.F. Efforts of the Custodian of the Two Holy Mosques in the education of Muslim children through scholarships offered by the Islamic University. J. Islamic Univ. Sharia Sci. 2003, 35, 386-488.

6. Al-Qarni, H.B.A. Some scholarship students' problems in Tabuk University and procedural mechanisms to address them (field study). J. Educ. Sci. 2018, 13, 103-157.

7. Al-Shehry, A.M. An Investigation of the Financial and Academic Problems Perceived by Saudi Graduate Students while They Are Studying in the United States. Doctoral Dissertation, Oregon State University, Corvallis, OR, USA, 1989, unpublished.

8. Srikatanyoo, N.; Gnoth, J. Country image and international tertiary education. J. Brand Manag. 2002, 10, 139-146. [CrossRef]

9. Hohner, M.; Tsigaris, P. Students' perception of quality for a business program delivered in Canada and China. J. Int. Educ. Bus. 2012, 5, 37-49. [CrossRef]

10. Jones, S.R.; Torres, V.; Armino, J. Negotiating the Complexities of Qualitative Research in Higher Education: Fundamental Elements and Issues; Routledge: New York, NY, USA, 2006.

11. Kalafatis, S.; Ledden, L. Carry-over effects in perceptions of educational value. Stud. High. Educ. 2013, 38, 1540-1561. [CrossRef]

12. Kearney, M.; Lincoln, D. The international student experience: Voices and perspectives. Stud. High. Educ. 2017, 42, 823-824. [CrossRef]

13. Kim, B.S.K.; Abreu, J.M. Acculturation measurement: Theory, current instruments, and future directions. In Handbook of Multicultural Counselling, 2nd ed.; Ponterotto, J.G., Casas, J.M., Suzuki, L.A., Alexander, C.M., Eds.; Sage Publications: Thousand Oaks, CA, USA, 2001; pp. 394-424. 
14. Kuo, B.; Roysircar, G. Predictors of acculturation for Chinese adolescents in Canada: Age of arrival, length of stay, social class, and English reading ability. J. Multicult. Couns. Dev. 2004, 32, 143-154. [CrossRef]

15. Lincoln, Y.S.; Lynham, S.A.; Guba, E.G. Paradigmatic controversies, contradictions, and emerging confluences, revisited. In The SAGE Handbook of Qualitative Research; Denzin, N.K., Lincoln, Y.S., Eds.; Sage Publications: Thousand Oaks, CA, USA, 2011; pp. 97-128.

16. Maxwell, J.A. Causal explanation, qualitative research, and scientific inquiry in education. Educ. Res. 2004, 33, 3-11. [CrossRef]

17. Merriam, S.B. Qualitative Research: A Guide to Design and Implementation, 2nd ed.; Jossey-Bass: San Francisco, CA, USA, 2009.

18. Mori, S.C. Addressing the mental health concerns of international students. J. Couns. Dev. 2000, 78, 137-144. [CrossRef]

19. Oberg, K. Culture shock: Adjustments to new cultural environments. Pract. Anthropol. 1960, 7, $177-182$. [CrossRef]

20. Pederson, P. The Five Stages of Culture Shock: Critical Incidents around the World; Greenwood Press: Westport, CT, USA, 1996.

21. Sam, D.L.; Berry, J.W. Acculturation: When individuals and groups of different cultural backgrounds meet. Perspect. Psychol. Sci. 2010, 5, 472-481. [CrossRef] [PubMed]

22. Sanchez-Fernandez, R.; Iniesta-Bonillo, M. The concept of perceived value: A systematic review of the research. Mark. Theory 2007, 7, 427-451. [CrossRef]

23. Gronroos, C. Quo vadis marketing? Towards a relationship marketing paradigm. J. Mark. 1994, 10, 347-360.

24. Altbach, P.G. Advancing the national and global knowledge economy: The role of research universities in developing countries. Stud. High. Educ. 2013, 38, 316-330. [CrossRef]

25. Smith, K. Assuring quality in transnational higher education: A matter of collaboration or control? Stud. High. Educ. 2010, 35, 793-806. [CrossRef]

26. Stake, R.E. Case studies. In Handbook of Qualitative Research; Denzin, N., Lincoln, Y., Eds.; Sage Publications: Thousand Oaks, CA, USA, 2000; pp. 435-454.

27. Thompson, E.R. Chinese perspectives on the important aspects of an MBA teacher. J. Manag. Educ. 2002, 26, 229-258. [CrossRef]

28. Choi, C.Q. Arabian brainpower. Sci. Am. 2008, 298, 18-19. [CrossRef]

29. Yakaboski, T.; Perez-Velez, K.; Almutairi, Y. Breaking the silence: Saudi graduate student experiences on a U. S. campus. J. Divers. High. Educ. 2017, 11, 221-238. [CrossRef]

30. Grey, M. Drawing with difference: Challenges faced by international students in an undergraduate business degree. Teach. High. Educ. 2002, 7, 153-166. [CrossRef]

31. Saudi Arabia Ministry of Education. 32,000 Scholarship from Students from 155 Countries in Saudi Universities. 30 December 2014. Available online: https://www.moe.gov.sa/ar/news/Pages/30-12-2014.aspx (accessed on 4 December 2019).

32. Saudi Arabian Cultural Mission. Welcome to SACM. 2015. Available online: http://www.sacm.org/default. aspx (accessed on 11 November 2019).

33. Yin, R.K. Case Study Research: Design and Methods, 4th ed.; Sage Publication: Thousand Oaks, CA, USA, 2009.

34. Zheng, X.; Berry, J.W. Psychological adaptation of Chinese Sojourners in Canada. Int. J. Psychol. 1991, 26, 451-470. [CrossRef]

35. Buchanan, F.R. International student perceptions of experience in the West. J. Int. Educ. Bus. 2019, 12, 147-166. [CrossRef]

36. Berry, J. Immigration, acculturation, and adaptation. Appl. Psychol. Int. Rev. 1997, 46, 5-68. [CrossRef]

37. Broido, E.M.; Manning, K. Philosophical foundations and current theoretical perspectives in qualitative research. J. Coll. Stud. Dev. 2002, 43, 434-445.

38. Colaizzi, P. Psychological research as a phenomenologist views it. In Existential-Phenomenological Alternatives for Psychology; Valle, R.S., King, M., Eds.; Oxford University Press: Oxford, UK, 1978; pp. 48-71.

39. Creswell, J.W. Research Design: Qualitative, Quantitative, and Mixed Methods Approaches, 4th ed.; Sage Publications: Thousand Oaks, CA, USA, 2014.

40. Denzin, N.K.; Lincoln, Y.S. The SAGE Handbook of Qualitative Research; Sage Publications: Thousand Oaks, CA, USA, 2011. 
41. DeWalt, K.M.; DeWalt, H.R. Participant Observation: A Guide for Fieldworkers; AltaMira Press: Walnut Creek, CA, USA, 2002.

42. Gibbs, G. Analyzing Qualitative Data; Sage Publications: Thousand Oaks, CA, USA, 2007.

43. Aba Al-Khail, S. Student care for international student scholarships in the Kingdom of Saudi Arabia. In Proceedings of the Custodian of the Two Holy Mosques Forum for Graduates of Saudi Universities from Southeast Asia, Kuala Lumpur, Malaysia; Imam Muhammad Bin Saud Islamic University Press: Riyadh, Saudi Arabia, 2000.

44. Zhou, Y.; Jindal-Snape, D.; Topping, K.; Todman, J. Theoretical models of culture shock and adaptation in international students in higher education. Stud. High. Educ. 2008, 33, 63-75. [CrossRef]

C 2020 by the author. Licensee MDPI, Basel, Switzerland. This article is an open access article distributed under the terms and conditions of the Creative Commons Attribution (CC BY) license (http://creativecommons.org/licenses/by/4.0/). 